\title{
A REVIEW OF THE IN VITRO PROPAGATION OF BAUHINIA SPP.
}

\author{
Jaime A. TEIXEIRA DA SILVA \\ P. O. Box 7, Miki-cho post office, Ikenobe 3011-2, Kagawa-ken, 761-0799, Japan \\ Received: March 15, 2013; Accepted: July 8, 2013
}

\begin{abstract}
Bauhinia species (including B. acuminata, B. variegata, B. purpurea, B. monandra, B. galpinii, B. blakeana and $B$. acuminata) are popular ornamental plants, usually woody ornamentals or herbaceous lianas, with attractive flowers typical of the Leguminosae of arid, temperate, sub-tropical and tropical zones. Bauhinia species also serve as fodder and many have multiple medicinal and biological properties. There is an interest in commerce and amongst collectors to clonally propagate species from this genus. This review highlights protocols that currently exist for the in vitro culture of Bauhinia species as a means to clonally propagate material.
\end{abstract}

Key words: Bauhinia, liana, woody ornamental

\section{Multi-purpose nature of Bauhinia species}

Bauhinia species, named as such after Jean Bauhin and Gaspard Bauhin (Houghton Mifflin Co. 2009), are important ornamental, forest and medicinal plants, including climbers and trees. Bauhinia variegata Linn. Benth (Caesalpiniaceae), commonly referred to as the orchid tree in English, serves as a source of fire-wood and is thus important for agro-forestry, and is the most studied Bauhinia species. B. variegata is most frequently found in tropical climates and is known to restore fertility to acid and degraded soils because of its ability to fix nitrogen (Acharya and Kafle 2009). B. vahlii is also used as a phytoremediative species in the Himalayan region (Dhar and Upreti 1999). In Nepal, the flowers are used in curries and as fodder for cattle (Singh et al. 2012). B. variegata has numerous medicinal properties; among them antiinflammatory and antibacterial activity (Rajkapoor et al. 2006; Parekh and Chanda 2007). Bauhinia racemosa is a sacred Hindu tree whose bark is used to treat inflammation, chronic dysentery, diarrhea, glandular inflammations, ulcer, goiter and some skin diseases (Rajanna et al. 2011). Bioactivities include anti-inflammatory, analgesic, antipyretic (Gupta et al. 2005), antitumor, antioxidant, antimicrobial (Gupta et al. 2004; Kumar et al.
2005), antiulcer (El-Hossary et al. 2000) and antibacterial (Dahikar et al. 2011), mainly by the leaves and bark. The aerial parts of Bauhinia cheilantha (Bong.) Steud., known as mororó or pata-de-vaca in Portuguese, is a common leguminous plant in the Caatinga (principal ecosystem in Brazil's semi-arid regions) that has value as a fodder crop and for its medicinal properties: antiinflammatory, antidiabetic, sedative, antiparisitic, digestive and expectorant (Lorenzi and Matos 2008). In addition to their medicinal properties, many Bauhinia species have tremendous horticultural and ornamental potential, and are commonly used as garden shrubs or pot plants due to their exuberant flowers. They are particularly useful as a spreading liana-type bush for garden walls, or, in a tree form, as a landscape plant. There are no documented studies on postharvest management of cut flowers of any Bauhinia species, but cut flowers make an attractive bouquet with an estimated lifespan of a few days without any special treatment.

Bauhinia species can be propagated through conventional sexual and vegetative means, although the process is time-consuming and has several restrictions, including a long time gap between pod formation and maturation (Jorge et al. 2005), and strong inhibition of germination imposed by the testa (Prasad and Nautiyal 1996). 
Considering the importance of various $\mathrm{Bau}$ hinia species, either in agro-forestry or in medicine, there is interest in the in vitro culture and micropropagation of these species (Bhattacharya et al. 2000). Even though such studies are limited, this review compiles the current literature on $\mathrm{Bau}$ hinia species with the aim of providing a useful platform for further in vitro studies and applied biotechnological applications. Currently very few molecular studies exist on Bauhinia species (Lau et al. 2005), and providing a tissue culture protocol would allow studies on molecular and biotechnological aspects to be expanded.

\section{In vitro seed germination, culture and micro- propagation of Bauhinia species}

\section{General considerations}

Mathur and Mukunthakumar (1992) first noted the importance of micropropagation of $B$. variegata as a rapid means of producing clonal plant stock for afforestation, woody biomass production and conservation of elite germplasm. Kumar (1992) used mature ex vitro material and, using the protocol noted in Fig. 1, could induce callus and shoots, which could be rooted in vitro. Bauhinia species can be propagated in vitro through microshoots proliferation (Upreti and Dhar 1996) or by elongation of nodal buds (Singh et al. 2012). In addition, Bauhinia species can be regenerated from calli formed on in vitro hypocotyls through organogenesis (Mello et al. 2001) or by somatic embryos (Banerjee et al. 2012), the latter making automation of $B$. variegata micropropagation possible. Most commonly, in vitro propagated Bauhinia plants are derived from in vitro seed germination, and Singh et al. (2012) provide a simple, but apparently effective, protocol for seed sterilization for germination in vitro. This protocol can serve for the in vitro germination of other Bauhinia species, including Bauhinia galpinii (Teixeira da Silva, unpublished results; Fig. 2). Although more difficult, Bauhinia cultures can be also initiated from mature plants (Kumar 1992; Mathur and Mukunthakumar 1992; Dhar and Upreti 1999; Kumar et al. 2005), but browning of explants may be a problem (Dhar and Upreti 1999).

\section{Species-by-species description}

An alphabetical description is provided next of the in vitro response of different Bauhinia species. All in vitro studies were performed at $25^{\circ} \mathrm{C}$, unless specified otherwise.

Akhter et al. (2012) could germinate $95 \%$ of B. acuminata seeds on Murashige and Skoog (1962) (MS) basal medium containing 3\% (w/v) sucrose and supplemented with $1 \mathrm{mg} \cdot \mathrm{dm}^{-3}$ gibberellic acid $\left(\mathrm{GA}_{3}\right)$ under a 12-h photoperiod at 3000 Lux. When the nodes of 4- or 5-week-old seedlings were transferred to MS containing $0.5 \mathrm{mg} \cdot \mathrm{dm}^{-3} 6$ benzyladenine (BA; equivalent to BAP or 6benzylaminopurine; Teixeira da Silva 2012) and $0.1 \mathrm{mg} \cdot \mathrm{dm}^{-3} \alpha$-napthaleneacetic acid (NAA), 2.5 shoots per explant formed and when shoots were transferred to MS containing $0.6 \mathrm{mg} \cdot \mathrm{dm}^{-3} \mathrm{NAA}$ and $5 \%(\mathrm{v} / \mathrm{v})$ coconut water $(\mathrm{CW}), 3.44$ roots formed per shoot.

Gutiérrez et al. (2011a, 2011b), working with B. cheilantha, used Woody Plant Medium (WPM; Lloyd and McCown 1980) basal medium containing $3 \%(\mathrm{w} / \mathrm{v})$ sucrose to regenerate shoots from nodal segments of 20-day-old in vitro seedlings under $60 \mu \mathrm{mol} \cdot \mathrm{m}^{-2} \cdot \mathrm{s}^{-1}$ photosynthetic photon flux density (PPFD) and a 16-h photoperiod. When $2 \mathrm{mg} \cdot \mathrm{dm}^{-3}$ BA (2011a study) or $1 \mathrm{mg} \cdot \mathrm{dm}^{-3}$ thidiazuron (TDZ) and $2 \mathrm{mg} \cdot \mathrm{dm}^{-3} \mathrm{BA}$ were added to the medium (2011b study), 2.84 shoots formed per nodal explant, 2.4-fold more than per cotyledon. The addition of $0.5 \mathrm{mg} \cdot \mathrm{dm}^{-3}$ indole-3-acetic acid (IAA), $1.0 \mathrm{mg} \cdot \mathrm{dm}^{-3} \mathrm{NAA}$ or $0.25 \mathrm{mg} \cdot \mathrm{dm}^{-3}$ indole3-butyric acid (IBA) resulted in best rooting percentage $(\sim 65.0 \%)$ while $0.5 \mathrm{~g} \cdot \mathrm{dm}^{-3}$ activated charcoal (AC) improved shoot and root formation. The authors also found that forced ventilation through a polyvinylchloride film during rooting increased the percentage of seedling survival during greenhouse acclimatization.

In B. forficata, two studies exist. Shoots have been shown to originate from cotyledonary node epidermal and subepidermal tissue through a process of indirect organogenesis and amitosis (nuclear fragmentation) (Appezzato-da-Glória and Machado 2004). In that study, half-strength MS ( $1 / 2$ MS) basal medium to which $3 \%(\mathrm{w} / \mathrm{v})$ sucrose and $4 \mathrm{mg} \cdot \mathrm{dm}^{-3}$ BA were added allowed callus to form from $1 \mathrm{~cm}$ long hypocotyls after 30 days when cultured under $30 \mu \mathrm{mol} \cdot \mathrm{m}^{-2} \cdot \mathrm{s}^{-1}$ PPFD with a $16-\mathrm{h}$ 
photoperiod. Mello et al. (2000) obtained adventitious buds of $B$. forficata from callus grown on hypocotyl segments. Callus was initiated on $1 / 2 \mathrm{MS}$ medium with $30 \mathrm{~g} \cdot \mathrm{dm}^{-3}$ sucrose, 2 and $4 \mathrm{mg} \cdot \mathrm{dm}^{-3}$ $\mathrm{BA}$, at $30 \mu \mathrm{mol} \cdot \mathrm{m}^{-2} \cdot \mathrm{s}^{-1}$ PPFD and a $16-\mathrm{h}$ photoperiod, with a frequency of 5-6 buds/ $0.5 \mathrm{~g}$ callus. Shoots elongated when transferred to BA-free medium. In a subsequent study, Mello et al. (2001) found that exposure of seedling-derived hypocotyls to $17.7 \mu \mathrm{M}$ BA induced callus on MS basal medium with $3 \%(\mathrm{w} / \mathrm{v})$ sucrose under a $16-\mathrm{h}$ photoperiod at $30 \mu \mathrm{mol} \cdot \mathrm{m}^{-2} \cdot \mathrm{s}^{-1}$ PPFD. Cell suspension cultures could be induced from $5 \mathrm{~g}$ of callus placed in 100 $\mathrm{ml}$ of liquid callus-inducing medium at $60 \mathrm{rpm}$ in $250-\mathrm{cm}^{3}$ Erlenmeyer flasks, when subcultured every 3 weeks. Galactose, sorbitol and glycerol could not support cell suspension cultures, only sucrose.

Kumar (1992) used ex vitro stem cuttings from young branches of 15-18-year old B. purpurea trees which, after surface sterilization (Fig. 1), were trimmed to $0.5-\mathrm{cm}$ explants. When placed on MS basal medium containing 3\% (w/v) sucrose under $40 \mu \mathrm{mol} \cdot \mathrm{m}^{-2} \cdot \mathrm{s}^{-1}$ PPFD and a 12-h photoperiod, callus could be induced with $10 \mu \mathrm{M}$ 2,4dichlorophenoxyacetic acid (2,4-D), and after subculture every 30 days, shoots could be induced with $5 \mu \mathrm{M}$ kinetin (Kin), while roots could be induced within 30 days in the presence of $5 \mu \mathrm{M}$ NAA.

\section{Bauhinia purpurea stem cuttings}

Stir cuttings vigorously in $20 \%$ (v/v) Teepol (soapy detergent)

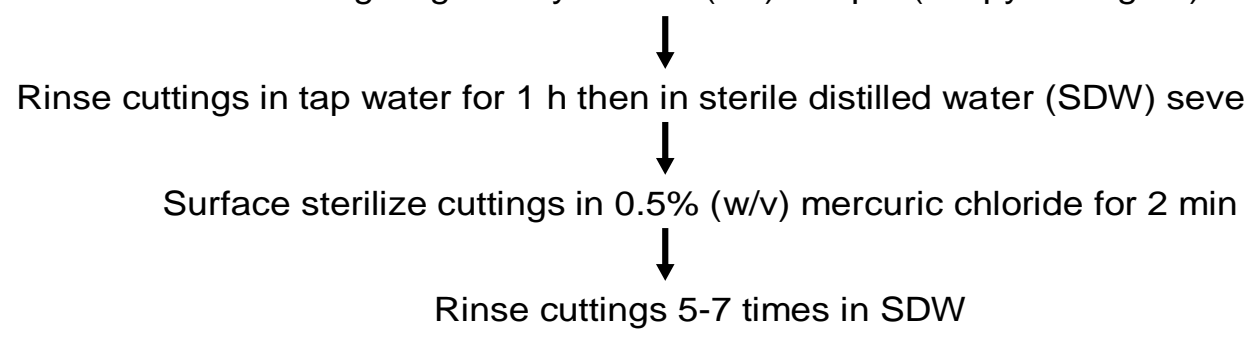

Bauhinia vahlii stem cuttings/lianas

Wipe cuttings/lianas with $80 \%$ ethanol using a cloth

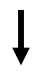

Disinfect cuttings/lianas in 2\% Teepol (soapy detergent) for $5 \mathrm{~min}$

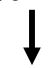

Surface sterilize cuttings/lianas in $80 \%$ ethanol for $30 \mathrm{sec}$

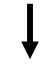

Surface sterilize cuttings/lianas in $0.1 \%(\mathrm{w} / \mathrm{v})$ mercuric chloride for $10 \mathrm{~min}$

Rinse cuttings/lianas in sterile double-distilled water several times

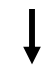

Trim terminal ends of explants

Rinse cuttings/lianas with $50 \mathrm{mg} / \mathrm{l}$ ascorbic acid $+75 \mathrm{mg} / \mathrm{l}$ citric acid to prevent browning

Figure 1. Surface sterilization protocol for Bauhinia spp. ex vitro-derived stem cuttings (1 cm long) from actively growing branches of mature (15-18 years old) trees based on Kumar's (1992) protocol for B. purpurea or for mature stem cuttings or lianas (3-4 cm long, each with one node) from B. vahlii (Dhar and Upreti 1999). 


\section{Bauhinia variegata seeds}

Wash seeds in water containing a few drops of Teepol (soapy detergent)

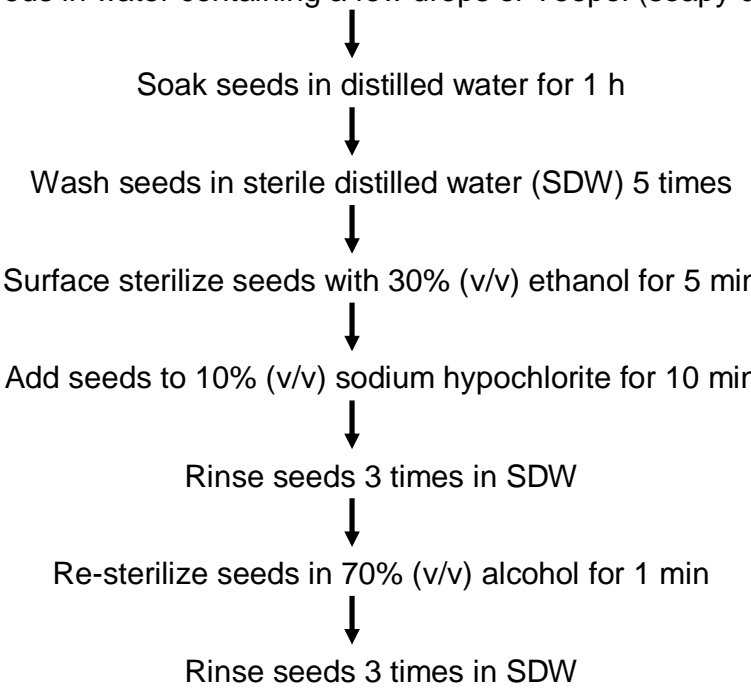

Bauhinia vahlii seeds

Soak seeds in distilled water for $12 \mathrm{~h}$

$\downarrow$

Wash seeds in 5\% Teepol (soapy detergent). Rinse thoroughly with distilled water

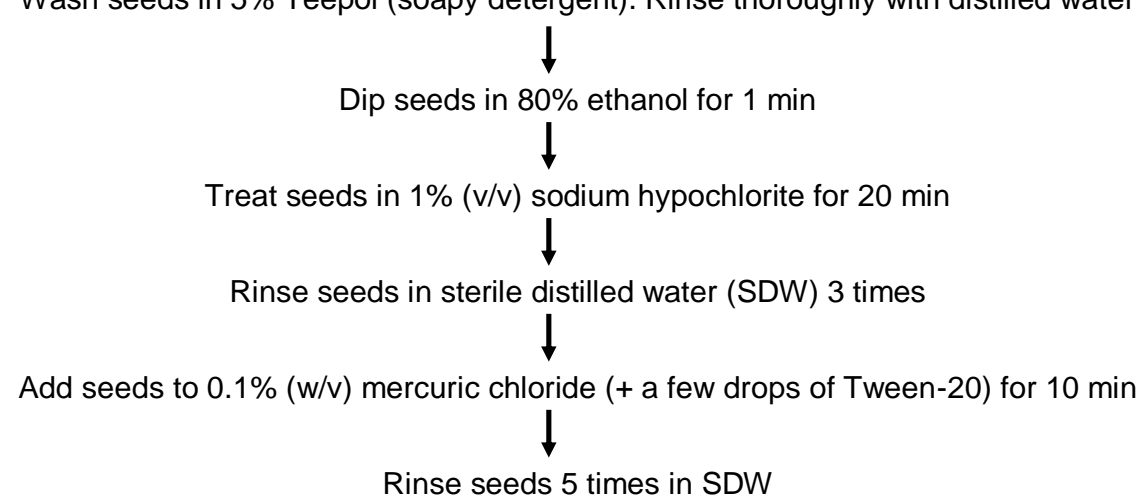

Figure 2. Surface sterilization for Bauhinia spp. seeds based on Singh et al.'s (2012) protocol for B. variegata and on a protocol for B. vahlii (Upreti and Dhar 1996). This B. variegata protocol works well for B. galpinii seed (Teixeira da Silva, unpublished data).

Only a single study exists for $B$. tomentosa (Naz et al. 2012). Nodal explants from in vitro seedlings could form 12 shoots per explant after 6 weeks on MS medium containing $50 \mathrm{mg} \cdot \mathrm{dm}^{-3}$ adenine sulphate (AS), $5.0 \mu \mathrm{M}$ BA and $0.5 \mu \mathrm{M}$ NAA. Roots were induced in the presence of $5.0 \mu \mathrm{M}$ chlorogenic acid and $2.5 \mu \mathrm{M}$ IBA from $70 \%$ of shoots within 4 weeks. MS was more effective than WPM as a basal medium. Polyvinylpyrrolidone and ascorbic acid were able to reduce polyphenolics in vitro.
B. vahlii cotyledonary nodes from 15-d old in-vitro-germinated seedlings could form 5.5 shoots per explant on MS medium containing $20 \mathrm{~g} \cdot \mathrm{dm}^{-3}$ sucrose, $1 \mu \mathrm{M} \mathrm{TDZ}$, at $40 \mu \mathrm{mol} \cdot \mathrm{m}^{-2} \cdot \mathrm{s}^{-1} \mathrm{PPFD}$ under a 16-h photoperiod (Upreti and Dhar 1996). This medium served equally well for shoot induction and proliferation. MS as basal medium was more effective than B5 (Gamborg et al. 1968), WPM or $1 / 2$ MS. Some success in inducing shoots was possible with $1 \mu \mathrm{M}$ BA, $1 \mu \mathrm{M}$ Kin, or $2.5 \mu \mathrm{M}$ zeatin. 
$55 \%$ of shoots formed roots on $1 / 2$ MS medium with $1 \mu$ M NAA. Dhar and Upreti (1999) used nodes of mature lianas as explants. They were initially incubated in the dark at $4{ }^{\circ} \mathrm{C}$ for $48 \mathrm{~h}$ then plated on MS basal medium containing $100 \mathrm{mg} \cdot \mathrm{dm}^{-3}$ AS and $2.5 \mu \mathrm{M}$ Kin to induce and proliferate shoots, forming a maximum of 4.5 shoots per explant at $40 \mu \mathrm{mol} \cdot \mathrm{m}^{-2} \cdot \mathrm{s}^{-1}$ PPFD and under a $16-\mathrm{h}$ photoperiod. Browning could be reduced by soaking sterilized explants in a solution of $50 \mathrm{mg} \cdot \mathrm{dm}^{-3}$ ascorbic acid and $75 \mathrm{mg} \cdot \mathrm{dm}^{-3}$ citric acid. In vitro-derived rootless plantlets formed roots in $1 / 2$ MS liquid medium with NAA and IBA ( $10 \mu \mathrm{M}$ of either) in which $55.5 \%$ of plantlets rooted. Bhatt and Dhar (2000) induced 12.6 shoots per cotyledonary node in the first culture, dropping slightly to 12.0 by the fourth subculture. Shoot formation was possible on MS basal medium containing 3\% (w/v) sucrose, $1 \mu \mathrm{M}$ TDZ and $1 \mu \mathrm{M}$ Kin (with or without $1 \mu \mathrm{M}$ $\mathrm{GA}_{3}$ ). $83 \%$ of plantlets could form roots on the same basal medium containing $1 \mu \mathrm{M}$ NAA. Both roots and shoots were formed under $40 \mu \mathrm{mol} \cdot \mathrm{m}^{-2} \cdot \mathrm{s}^{-1}$ PPFD and a 16-h photoperiod.

B. variegata is the most studied Bauhinia species. Mathur and Mukunthakumar (1992) used nodal explants of mature trees to induce 7.8 shoots per nodal segment in the presence of $13.3 \mu \mathrm{M}$ BA on MS basal medium containing 3\% (w/v) sucrose and $100 \mathrm{mg} \cdot \mathrm{dm}^{-3} m y o$-inositol at a PPFD of $36 \mu \mathrm{mol} \cdot \mathrm{m}^{-2} \cdot \mathrm{s}^{-1}$ and under a $16-\mathrm{h}$ photoperiod at $28{ }^{\circ} \mathrm{C}$. $96 \%$ of shoots rooted in the presence of $4.9 \mu \mathrm{M}$ IBA. Thonnalak (2012) used axillary meristems as explants to induce shoots on MS basal medium containing $2.5 \mathrm{mg} \cdot \mathrm{dm}^{-3} \mathrm{BA}$, although callus formed when the BA concentration exceeded $5 \mathrm{mg} \cdot \mathrm{dm}^{-3}$. Shoots could be proliferated with 1-2.5 $\mathrm{mg} \cdot \mathrm{dm}^{-3} \mathrm{BA}$ at $2500 \mathrm{Lux}$ and a $16-\mathrm{h}$ photoperiod and formed roots when exposed to $5 \mathrm{mg} \cdot \mathrm{dm}^{-3}$ NAA. Papafotiou et al. (2010) chose to use ex vitro-derived shoot tips and single node explants from young shoots ( 25 or $80 \mathrm{~cm}$ long) with four apical nodes, which developed after pruning oneyear old seedlings, as explants. The authors also tested shoot tip or single node explants from 3-leaf (two-week old) seedlings. Explants of the $3^{\text {rd }}, 4^{\text {th }}$ and $5^{\text {th }}$ node had a $70-100 \%$ response and 1.5 $2.0 \mathrm{~cm}$ shoots with 3-5 leaves represented the most effective shoot formation on MS basal medium containing $3 \%(\mathrm{w} / \mathrm{v})$ sucrose and $0.5-1.0 \mathrm{mg} \cdot \mathrm{dm}^{-3}$ BA. Explants excised from $25 \mathrm{~cm}$ long shoots or from young seedlings containing three leaves formed more shoots than $80 \mathrm{~cm}$ long shoots. Leaf lamina explants formed callus on MS containing 2,4-D and BA, but callus failed to form shoots. Roots were induced on $1 / 2$ MS medium with $2 \mathrm{mg} \cdot \mathrm{dm}^{-3}$ IBA. In $B$. variegata, both picloram (Pic) and 2,4-D successfully induced somatic embryos either through a direct route or an indirect route (i.e., via callus) from the sub-epidermis of cotyledons or hypocotyls (Banerjee et al. 2012). Sterilized seeds were germinated in vitro, and cotyledons and hypocotyls were used as explants. Somatic embryogenesis was possible on MS basal medium with B5 vitamins at $40 \mu \mathrm{mol} \cdot \mathrm{m}^{-2} \cdot \mathrm{s}^{-1}$ PPFD and a 16-h photoperiod. Basal medium contained 4-6 $\mathrm{mg} \cdot \mathrm{dm}^{-3}$ Pic for cotyledons and hypocotyls, 6$8 \mathrm{mg} \cdot \mathrm{dm}^{-3} 2,4-\mathrm{D}$ for cotyledons but $12 \mathrm{mg} \cdot \mathrm{dm}^{-3}$ for hypocotyls. Using $4 \mathrm{mg} \cdot \mathrm{dm}^{-3}$ Pic, 84 somatic embryos (SEs) formed per cotyledon and 49 SEs per hypocotyl. Using $8 \mathrm{mg} \cdot \mathrm{dm}^{-3}$ 2,4-D, 52 SEs formed per cotyledon and 12 SEs per hypocotyl. SEs could also be induced from friable callus that formed on Pic- and 2,4-D-containing medium. Using callus induced on $6 \mathrm{mg} \cdot \mathrm{dm}^{-3} \mathrm{Pic}$, $84 \mathrm{SEs}$ were induced per cotyledon and 49 SEs per hypocotyl. Using callus induced on $8 \mathrm{mg} \cdot \mathrm{dm}^{-3} 2,4-\mathrm{D}, 53 \mathrm{SEs}$ were induced per cotyledon and 19 SEs per hypocotyl. 0.2 $\mathrm{mg} \cdot \mathrm{dm}^{-3}$ BA was required for best rooting of SEderived plantlets. Singh et al. (2012) decided to use nodes of seedlings germinated in vitro as explants. On MS basal medium containing 3\% (w/v) sucrose and supplemented with $1 \mu \mathrm{M}$ BA and $0.05 \mu \mathrm{M}$ $\mathrm{NAA}$, and under $40 \mu \mathrm{mol} \cdot \mathrm{m}^{-2} \cdot \mathrm{s}^{-1}$ PPFD and a $16-\mathrm{h}$ photoperiod, 7.45 nodes formed per shoot within 8 weeks. Callus was profuse and as wide as $11 \mathrm{~mm}$.

\section{Acclimatization of Bauhinia species}

According to Singh et al. (2012), shoots that form in vitro and that have rooted well can be trimmed to plantlets containing 3-4 nodes $2-3 \mathrm{~cm}$ in size and the plantlets can be rooted in a mixture of $1: 1$ sand and soil (based on Kumar 1992) with fungicides added. For rooting, the plantlets were kept at high humidity for 2 weeks. Watering with $1 / 10$ - 
strength MS medium was sufficient for the survival of B. variegata plantlets in soil (Mathur and Mukunthakumar 1992). Thonnalak (2012) showed $64 \%$ plantlet survival after transfer to peat moss in the field. A 1:1 mixture of soil and vermiculite was optimal for B. vahlii (Dhar and Upreti 1999), although Bhatt and Dhar (2000) suggested a 2:1:1 mixture of soilrite, sand and soil.

\section{Future perspectives}

Studies on the in vitro culture of Bauhinia species are still at a nascent phase of exploration. As their medicinal and ornamental value increase, greater attention will be paid to tissue culture. Reliable protocols exist thus far for the micropropagation of several Bauhinia species but several options for germplasm improvement through biotechnology should be explored in the future. The use of thin cell layers (TCLs) (Teixeira da Silva and Dobránszki 2013a, b) and rigorous attention to explant size and sampling would allow for greater control of organogenesis while synthetic seed technology (Sharma et al. 2013) would allow for short- to long-term storage of important germplasm. The use of phloroglucinol to improve rooting (Teixeira da Silva et al. 2013) could further enhance acclimatization.

\section{REFERENCES}

Acharya A., Kafle N. 2009. Land degradation issues in Nepal and its management through agro forestry. J. Agric. Envir. 10(1): 115-123.

Akhter M.S., Rahman S.M.M., Rahman M.H. 2012. Micropropagation of Bauhinia acuminata L. Int. Res. J. Applied Life Sci. 1(3): 35-43.

Appezzato-da-Glória $\quad$ B., Machado S.R. 2004. Ultrastructural analysis of in vitro direct and indirect organogenesis. Rev. Bras. Bot. 27(3): 429437.

Banerjee P., Maity S., Banerjee N. 2012. High frequency somatic embryogenesis and plantlet regeneration of Bauhinia variegata, a multipurpose tree legume. Indian J. Fundamental Applied Life Sci. 2(2): 87-95.

Bhatt I.D., Dhar U. 2000. Combined effect of cytokinin on multiple shoot production from cotyledonary node explants of Bauhinia vahlii. Plant Cell, Tissue Organ Cult. 62: 79-83.
Bhattacharya S., Dasgupta S., Chatterjee P. 2000. In vitro regeneration of plantlets from seedling explants of different species of Bauhinia L. Plant Tissue Cult. 10: 103-109.

Dahikar S.B., Bhutada S.A., Tambekar D.H., Vibhute S.K., Kasture S.B. 2011. In-vitro anti-bacterial efficacy of solvent extracts of leaves of Bauhinia racemosa Lam. (Caesalpiniaceae) against enteric bacterial pathogens. Int. J. Pharma. Sci. Drug Res. 3(1): 32-34.

Dhar U., Upreti J. 1999. In vitro regeneration of a mature leguminous liana (Bauhinia vahlii Wight \& Arnott). Plant Cell Rep. 18(7/8): 664-669.

El-Hossary G.A., Selim M.A., Sayed A.E., Khaleel A.E. 2000. Study of the flavonoid content of Bassia muricata and Bauhinia racemosa. Bull. Fac. Pharmacy, Cairo Univ. 38: 93-97.

Gamborg O.L., Miller R.A., Ojima K. 1968. Nutrient requirements of suspension cultures of soybean root cells. Exp. Cell Res. 50: 151-158.

Gupta M., Mazumder U.K., Kumar R.S., Gomathi P., Rajeshwar Y., Kakoti B.B., Selven V.T. 2005. Anti-inflammatory analgesic and antipyretic effects of methanol extract from Bauhinia racemosa stem bark in animal models. J. Ethanopharmacol. 98(3): 267-273.

Gupta M., Mazumder U.K., Kumar R.S., Kumar T.S. 2004. Antitumor activity and antioxidant role of Bauhinia racemosa against Ehrlich ascites carcinoma in Swiss albino mice. Acta Pharmacol. Sin. 25(8): 1070-1076.

Gutiérrez I.E.M., Nepomuceno C.F., Ledo C.A. da S., Santana J.R.F. 2011a. Micropropagation and acclimatization of Bauhinia cheilantha (an important medicinal plant). African J. Biotechnol. 10(8): 1353-1358.

Gutiérrez I.E.M., Nepomuceno C.F., Ledo C.A. da S., Santana J.R.F. 2011b. In vitro regeneration of the Bauhinia cheilantha via organogenesis. Ciência Rural 41(2): 260-265.

Houghton Mifflin Co. 2009. Bauhinia. American Heritage Dictionary. The American Heritage ${ }^{\circledR}$ Dictionary of the English Language ( ${ }^{\text {th }} \mathrm{Ed}$.).

Jorge I., Ali M., Rocha J.O. 2005. Selective seed abortion affects the performance of the offspring in Bauhinia ungulata. Ann. Bot. 95: 1017-1023.

Kumar A. 1992. Micropropagation of a mature leguminous tree - Bauhinia purpurea. Plant Cell, Tissue Organ Cult. 31: 257-259.

Kumar R.S., Sivakumar T., Sunderam R.S., Gupta M., Mazumdar U.K., Gomathi P., Rajeshwar Y., 
Saravanan S., Kumar M.S., Murugesh K., Kumar K.A. 2005. Antioxidant and antimicrobial activities of Bauhinia racemosa L. stem bark. Braz. J. Medical Biol. Res. 38(7): 1015-1024.

Lau C.P.Y., Ramsden L., Saunders R.M.K. 2005. Hybrid origin of "Bauhinia blakeana" (Leguminosae: Caesalpinioideae), inferred using morphological, reproductive, and molecular data. Amer. J. Bot. 92(3): 525-533.

Lloyd G.B., McCown B.H. 1980. Commercially feasible micropropagation of mountain laurel, Kalmia latifolia, by use of shoot-tip culture. Proc. Int. Plant Prop. Soc. 30: 421-427.

Lorenzi H., Matos F.J.A. 2008. Plantas Medicinais no Brasil: Nativas e Exóticas. $2^{\text {nd }}$ ed. Nova Odessa, São Paulo, Brazil.

Mathur J., Mukunthakumar S. 1992. Micropropagation of Bauhinia variegata and Parkinsonia aculeata from nodal explants of mature trees. Plant Cell, Tissue Organ Cult. 28(1): 119-121.

Mello M.O., Dias C.T.S., Amaral A.F.C., Melo M. 2001. Growth of Bauhinia forficata Link, Curcuma zedoaria Roscoe and Phaseolus vulgaris L. cell suspension cultures with carbon sources. Sci. Agric. 58(3): 481-485.

Mello M.O., Melo M., Appezato-da Gloria B. 2000. Bauhinia forficata Link shoot regeneration: Histological analysis of organogenesis pathway. Brazilian Arch. Biol. Technol. 43(4): 6.

Murashige T., Skoog F. 1962. A revised medium for rapid growth and bioassays with tobacco tissue cultures. Physiol. Plant. 15: 473-499.

Naz R., Anis M., Aref I.M. 2012. Assessment of the potentiality of TDZ on multiple shoot induction in Bauhinia tomentosa L., a woody legume. Acta Biol. Hung. 63: 474-482.

Papafotiou M., Antoniou I., Akoumianaki-Ioannidou A. 2010. Studies on in vitro propagation of Bauhinia variegate. Acta Hort. 885: 263-266.

Parekh J., Chanda S. 2007. Evaluation of antibacterial activity and phytochemical analysis of Bauhinia variegata L. bark. African J. Biomed. Res. 10: 175-181.

Prasad P., Nautiyal A.R. 1996. Physiology of germination in Bauhinia: Involvement of seed coat in inhibition of germination in B. racemosa Lam seeds. Seed Sci. Technol. 24(2): 305-308.

Rajanna L.N., Sharanabasappa G., Seetharam Y.N., Aravind B., Mallikharjuna P.B. 2011. In vitro regeneration of cotyledonary node explant of $\mathrm{Bau}$ hinia racemosa. Bot. Res. Int. 4(4): 75-80.

Rajkapoor B., Jayakar B., Murugesh N., Saktisekharan D. 2006. Chemopreservation and cytotoxic effect of Bauhiunia variegata against $\mathrm{N}$ nitrosodiethylamine induced liver tumors and human cancer cell lines. J. Ethnopharmacol. 104: 407-409.

Sharma S., Shahzad A., Teixeira da Silva J.A. 2013. Synseed technology - A complete synthesis. Biotech. Adv. 31(2): 186-207.

Singh B.M., Wawrosch C., Joshi S.D., Kopp B. 2012. Micropropagation of Bauhinia variegata L. from tissue culture. Nepal J. Sci. Technol. 13(1): 39-41.

Teixeira da Silva J.A. 2012. Is BA (6-benzyladenine) BAP (6-benzylaminopurine)? Asian Australasian J. Plant Sci. Biotechnol. 6 (Special Issue 1): 121124.

Teixeira da Silva J.A., Dobránszki J. 2013a. How timing of sampling can affect the outcome of the quantitative assessment of plant organogenesis. Sci. Hortic. 159: 59-66.

Teixeira da Silva J.A., Dobránszki J. 2013b. Plant thin cell layers: a 40-year celebration. J. Plant Growth Reg. DOI 10.1007/s00344-013-9336-6.

Teixeira da Silva J.A., Dobránszki J., Ross S. 2013. Phloroglucinol in plant tissue culture. In Vitro Cell. Dev. Biol. - Plant 49(1): 1-16.

Thonnalak T. 2012. Tissue culture of orchid tree (Bauhinia variegata L.). Fac. Agric. Techol, Univ. Chiang Mai, Thailand, 12 p.

Upreti J., Dhar U. 1996. Micropropagation of Bauhinia vahlii Wight \& Arnott. - a leguminous liana. Plant Cell Rep. 16(3/4): 250-254. 